\title{
Orbital forcing of the East Antarctic ice sheet during the Pliocene and Early Pleistocene
}

\author{
M. O. Patterson ${ }^{1}$, R. McKay ${ }^{1 \star}$, T. Naish ${ }^{1}$, C. Escutia ${ }^{2}$, F. J. Jimenez-Espejo ${ }^{3}$, M. E. Raymo ${ }^{4}$, \\ S. R. Meyers ${ }^{5}$, L. Tauxe ${ }^{6}$, H. Brinkhuis ${ }^{7}$ and IODP Expedition 318 Scientists ${ }^{\dagger}$
}

The Pliocene and Early Pleistocene, between $\mathbf{5 . 3}$ and $\mathbf{0 . 8}$ million years ago, span a transition from a global climate state that was $2-3^{\circ} \mathrm{C}$ warmer than present with limited ice sheets in the Northern Hemisphere to one that was characterized by continental-scale glaciations at both poles. Growth and decay of these ice sheets was paced by variations in the Earth's orbit around the Sun. However, the nature of the influence of orbital forcing on the ice sheets is unclear, particularly in light of the absence of a strong 20,000-year precession signal in geologic records of global ice volume and sea level. Here we present a record of the rate of accumulation of iceberg-rafted debris offshore from the East Antarctic ice sheet, adjacent to the Wilkes Subglacial Basin, between 4.3 and 2.2 million years ago. We infer that maximum iceberg debris accumulation is associated with the enhanced calving of icebergs during ice-sheet margin retreat. In the warmer part of the record, between 4.3 and $\mathbf{3 . 5}$ million years ago, spectral analyses show a dominant periodicity of about 40,000 years. Subsequently, the powers of the 100,000-year and 20,000-year signals strengthen. We suggest that, as the Southern Ocean cooled between 3.5 and $\mathbf{2 . 5}$ million years ago, the development of a perennial sea-ice field limited the oceanic forcing of the ice sheet. After this threshold was crossed, substantial retreat of the East Antarctic ice sheet occurred only during austral summer insolation maxima, as controlled by the precession cycle.

G eological reconstructions of global ice volume ${ }^{1}$ and sea level ${ }^{2}$ during the Pliocene and Early Pleistocene (5-2 million years ago (Ma)) exhibit regular glacial-interglacial cycles occurring every 41 kyrs, paced by variations in Earth's axial tilt (obliquity). The absence of a strong $\sim 20$-kyr precession signal is confounding, because both obliquity and precession should impart a major influence on high-latitude summer insolation intensity, and therefore polar ice volume ${ }^{3}$. Indeed, precession is a major control on the orbital pacing of Late Pleistocene cycles ${ }^{1}$ and, although a number of hypotheses have been proposed to explain its absence before this time $e^{4-6}$, reconciliation of this conundrum remains hampered by the lack of direct observational evidence of orbital-scale PlioPleistocene variance of ice sheets, in particular from Antarctica ${ }^{7-9}$.

Integrated Ocean Drilling Program (IODP) core U1361 was recovered from $\sim 3,000 \mathrm{~m}$ water depth on the continental rise adjacent to the Wilkes Subglacial Basin of Antarctica, one of the largest marine-based sectors of the East Antarctic ice sheet (EAIS). Landward deepening reverse slope troughs penetrate beneath the EAIS, reaching depths of up to $2 \mathrm{~km}$ below sea level in this region ${ }^{10}$, heightening the vulnerability of this sector of the EAIS to marine ice sheet instabilities (Fig. 1). U1361 provides a well-dated, continuous geologic archive of Pliocene and Early Pleistocene orbital-scale variability of the EAIS marine margin. Sediment deposition at this site is controlled by the interplay between: downslope marine sediment gravity flows; the rainout of biogenic detritus from surface water plankton; iceberg rafting of terrigenous sediments; and low-energy bottom currents (Supplementary Information).

The studied interval consists of eighteen sedimentary cycles spanning an age range of 4.3-2.2 Ma, and comprising alternating terrigenous massive to laminated muds and diatom-rich/bearing silty-mud units (cycles 1-18 Fig. 2 and Supplementary Figs 2 and 3). In places, the muds contain packages of well-defined laminae and are consistent with established models of non-erosive overbank hemipelagic deposition onto a channel levee setting via turbidites on the lowermost Antarctic continental rise ${ }^{11}$. Steeply dipping, seaward prograding wedge sediments are evident in seismic reflection profiles across the continental shelf and extend onto the upper continental slope above seismic unconformity WL-U8 $(\sim 4.2 \mathrm{Ma}$; Supplementary Fig. 1; refs 12-14). The geometry of these strata is characteristic of grounding zone deposition by repetitive advances of a marine-based ice sheet to the shelf edge during glacial periods ${ }^{13}$. Sediment overloading near the shelf break at submarine canyon heads, in turn triggers turbidity currents down slope channels and leads to overbank deposition at the core site. Low-density turbidity currents in overbank 'distal' channel levee environments on the Antarctic continental rise are typically non-erosive ${ }^{11}$ (Supplementary Information). Thus, turbidite units are associated with periods of glacial advance to the Wilkes Land continental shelf edge, whereas bioturbated, diatom-rich/bearing facies represent warm interglacial periods of relatively ice-free ocean and increased primary productivity when the grounding line had migrated landward away from the shelf edge. Increased productivity during interglacial warm climates may be associated with enhanced upwelling of nutrientrich Circumpolar Deep Water (CDW; ref. 15) (Supplementary Information), which has been linked to southward expansion of the westerly wind field in response to a reduced pole-equator temperature gradient ${ }^{16}$. Presently, this relatively warm nutrient-rich CDW upwells to the surface north of the Southern Boundary Front of the

\footnotetext{
${ }^{1}$ Antarctic Research Centre, Victoria University of Wellington, Wellington 6140, New Zealand, ${ }^{2}$ Instituto Andaluz de Ciencias de la Tierra, CSIC-University of Granada, 18100 Armilla, Spain, ${ }^{3}$ Department of Biogeochemistry, Japan Agency for Marine-Earth Science and Technology, Yokosuka, Kanagawa, 237-0061, Japan, ${ }^{4}$ Lamont-Doherty Earth Observatory of Columbia University, PO Box 1000, 61 Route 9W, Palisades, New York 10964, USA, ${ }^{5}$ Department of Geoscience, University of Wisconsin-Madison, 1215 W. Dayton St. Madison, Wisconsin 53706, USA, ${ }^{6}$ Scripps Institution of Oceanography, La Jolla, California 92093-0220, USA, ${ }^{7}$ Marine Palynology and Paleoceanography, Laboratory of Paleobotany and Palynology, Utrecht University, Budapestlaan 4, 3584 CD Utrecht, Netherlands. ${ }^{\dagger}$ A full list of authors and their affiliations appears at the end of the paper. *e-mail: robert.mckay@vuw.ac.nz
} 


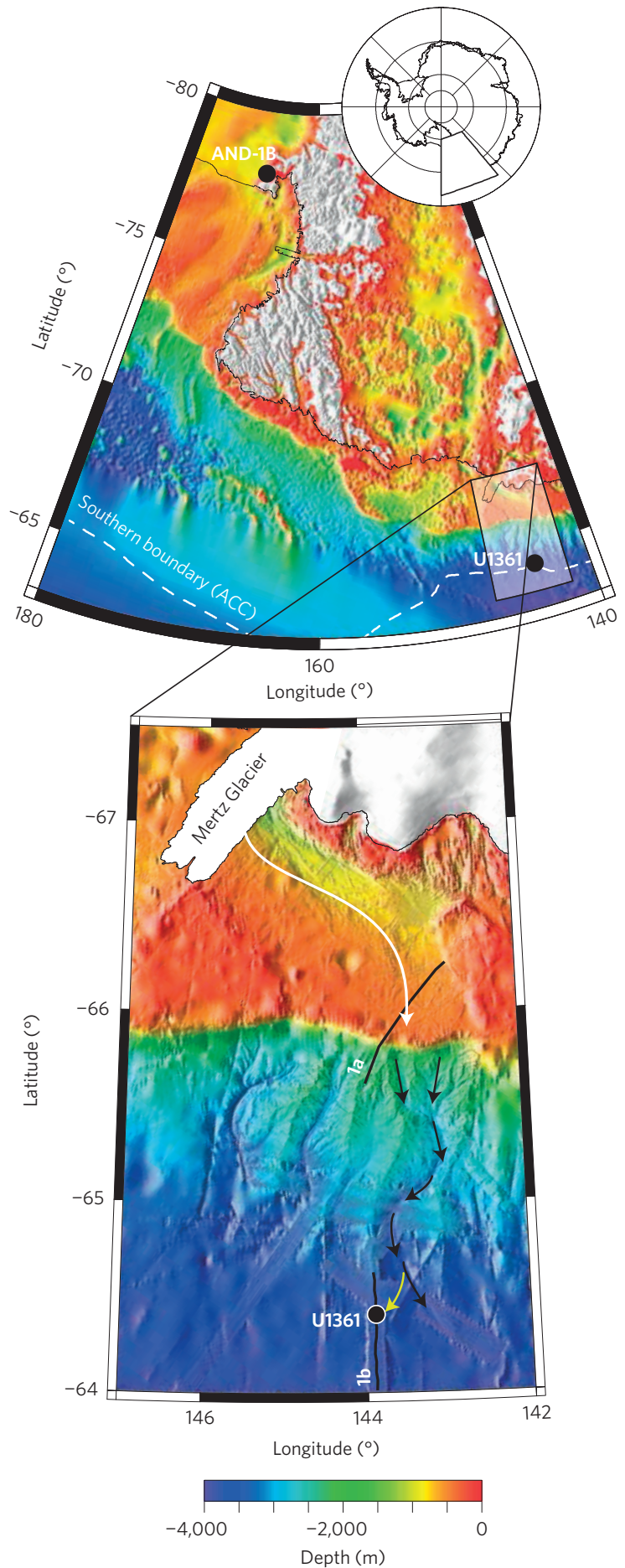

Figure 1 | Location of Site U1361 and bathymetry ${ }^{10}$ offshore of the Wilkes Land margin, Antarctica. Also shown is the location of the MiocenePleistocene ANDRILL AND-1B core recovered in the northwestern corner of the Ross Ice Shelf, the southern boundary of the Antarctic Circumpolar Current (ACC), the Mertz Glacier tongue and palaeo ice-sheet drainage path (white arrow) extending to the continental shelf edge, and the offshore slope and rise canyon system. Arrows represent downslope currents flowing into the Jussieu channel (black) with non-erosive overbank flow (yellow) towards the U1361 site on the continental rise. Black lines represent seismic reflection profile tracks represented in Supplementary Fig. 1a,b.

Antarctic Circumpolar Current and is marked by areas of enhanced productivity north of Site U1361 (Fig. 1).

We have developed a high-resolution record ( 3-4-kyr sample spacing) of iceberg-rafted debris (IBRD) mass accumulation rates
(MAR) for the U1361 core (Supplementary Table 1 and Fig. 2). Our age model is based on a magnetic polarity stratigraphy constrained by biostratigraphy ${ }^{12}$ and is not orbitally tuned (Supplementary Fig. 5). Thus, the age model for our primary spectral analyses (Fig. 3) assumes constant long-term sedimentation rates between polarity reversal tie points (Supplementary Information).

In general, the highest intensity of IBRD occurs during transitions from glacial terrigenous mud facies to interglacial diatom-rich/bearing muds up-core until $\sim 47 \mathrm{~m}$ below sea floor (mbsf), with most IBRD peaks immediately preceding diatom-rich facies and $\mathrm{Ba} / \mathrm{Al}$ peaks (Fig. 2). Isotopic $\mathrm{Nd}$ and $\mathrm{Sr}$ provenance indicators suggest that the terrigenous components in these diatomrich/bearing muds are associated with periods of glacial retreat of the ice margin back into the Wilkes Land Subglacial Basin during the Early Pliocene ${ }^{17}$. The Antarctic ice sheet loses the majority of its mass via iceberg calving and sub-ice-shelf melting ${ }^{18}$, which are intimately linked because enhanced ice-shelf melt leads to reduced buttressing, that in turn acts to enhance the flow of glacial tributaries, ultimately enhancing iceberg discharge $\mathrm{e}^{19}$. Icesheet reconstructions based on geologic data ${ }^{20}$ and modelling ${ }^{8}$ suggest that the above processes dominated Antarctic mass loss even during the warmest climates of the past $5 \mathrm{Myr}$. Thus, we interpret the maxima in IBRD MAR to be the consequence of accelerated calving during glacial retreat from marine terminating outlet glaciers along the Wilkes Land coastline, as well as a contribution from EAIS outlet glaciers entering the western Ross Sea (Supplementary Information). This interpretation is consistent with models and palaeodata that imply the most rapid mass loss of the EAIS margin during the last glacial termination occurred between 17 and $7 \mathrm{kyr}$ ago, and although this retreat was initiated by oceanic warming it was associated with enhanced iceberg discharge $\mathrm{e}^{21,22}$.

Spectral analysis of the untuned IBRD-MAR time series exhibits a dominant period of $\sim 40$ kyr between $\sim 4.2$ and $3.5 \mathrm{Ma}$ that transitions to strong and significant variance at $\sim 100-\mathrm{kyr}$ and $\sim 20$-kyr periods after $\sim 3.5 \mathrm{Ma}$, with a corresponding decrease in power of the $\sim 40-\mathrm{kyr}$ cycle (Figs 3 and 4 ). On the basis of the strong orbital relationship exhibited in frequency spectra of the untuned IBRD-MAR time series, the palaeomagnetic age model, and the apparent near-continuous long-term sedimentation (Supplementary Fig. 5), we established a nominal one-to-one correlation between cycles in ice margin variability expressed by our IBRD data and orbitally paced climatic time series (Fig. 2). Between 4.3 and $3.4 \mathrm{Ma}$, a strong visual correlation can be observed between 40 -kyr cycles in IBRD, mean annual insolation and the benthic $\delta^{18} \mathrm{O}$ global ice-volume record ${ }^{1}$, whereas between 3.3 and 2.2 Ma, IBRD cycles correlate with the $\sim 20-\mathrm{kyr}$ cycles of summer insolation at $65^{\circ} \mathrm{S}$ (Fig. 2). We acknowledge our visual correlations, although constrained by seven precisely dated palaeomagnetic reversals, do not represent a unique solution but are consistent with the variance in orbital frequencies implied by our spectral estimations.

Using these correlative relationships (Fig. 2) and our evolutionary spectral analyses on untuned IBRD data (Fig. 3), we then explore the role of longer-period orbital influences on the pattern of iceberg calving. The top of the $\sim 40$-kyr-dominated interval is marked by an $\sim 200$-kyr-long condensed section between $\sim 3.5$ and 3.3 Ma (Supplementary Fig. 5) and corresponds to a long-term $+1 \%$ glacial $\delta^{18} \mathrm{O}$ excursion punctuated by smaller interglacials spanning Marine Isotope Stages (MIS) MG5 and M2 (indicated by arrow in Fig. 2). The stratigraphic condensation, or possible erosion, at Site U1361 is associated with this glacial excursion. Indeed, this glacial excursion has also been associated with southern high-latitude climate cooling and the re-establishment of grounded ice on the middle to outer continental shelf in the Ross Sea following an $\sim 200$-kyr period of warm open ocean conditions ${ }^{7,9}$. Previous studies of older Oligocene and Miocene $\delta^{18} \mathrm{O}$ glacial excursions have proposed a relationship 


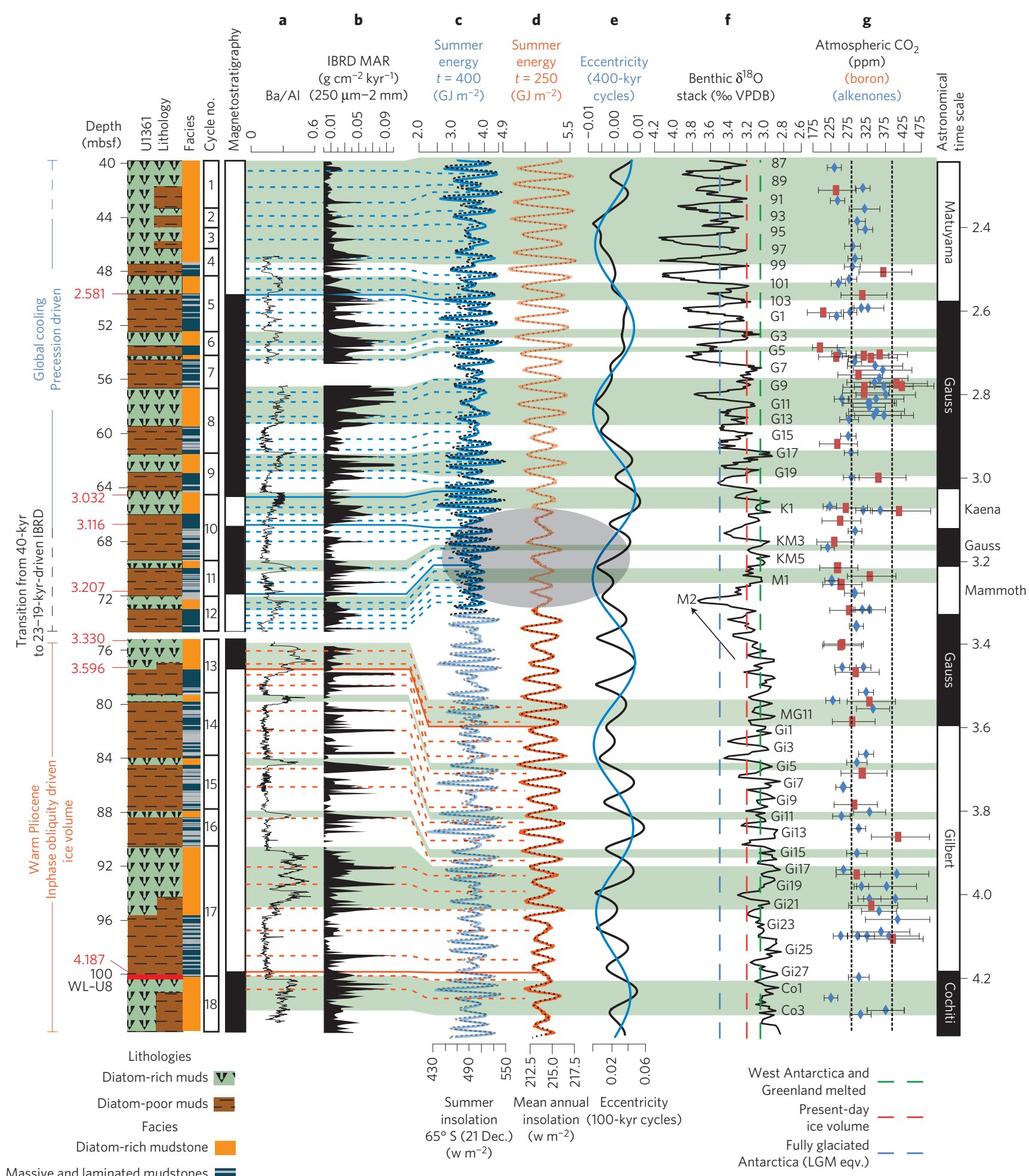

(Massive mud = blue Silt laminae $=$ grey)

Figure 2 | Depth series developed for IODP site U1361 sediment core between 4.4 and 2.2 Ma. a, XRF-based Ba/AI. b-f, IBRD MAR (b) correlated with January insolation and total integrated summer energy (melt threshold $[t]=400 \mathrm{GJ} \mathrm{m}^{-2}$ ) (c), mean annual insolation and total integrated summer energy (melt threshold $\left.[t]=250 \mathrm{GJ} \mathrm{m}^{-2}\right)(\mathbf{d})$, eccentricity ${ }^{39}(\mathbf{e})$, and the stacked benthic $\delta^{18} \mathrm{O}$ record $(\mathbf{f})$. Also shown are lithofacies, lithological cycles (transitional lithologies are represented by both symbols) and magnetic polarity stratigraphy ${ }^{12}$. Grey ellipse denotes alignment between a 1.2-Ma node in obliquity-modulated mean annual insolation and minimum in 400-kyr eccentricity and corresponds with MIS M2, a $1 \%$ o glacial $\delta^{18} \mathrm{O}$ excursion culminating with MIS M2 (arrow). $\mathbf{g}$, Atmospheric $\mathrm{CO}_{2}$ reconstructions based on boron isotopes and alkenones $31,32,43$.

between intervals of increased glacial amplitude in the $\delta^{18} \mathrm{O}$ record with a coincidence of $1.2-\mathrm{Myr}$ nodes in obliquity and $400-\mathrm{kyr}$ minima in long-period eccentricity ${ }^{23,24}$. This orbital configuration, which favours extended periods of cold summers and low seasonality, is considered optimal for Antarctic ice-sheet expansion, and occurs at $\sim 3.3 \mathrm{Ma}$ (Fig. $3 \mathrm{c}$ ) - the time of the transition from 
a

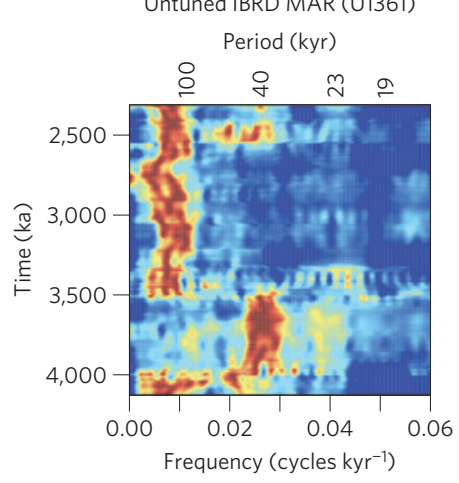

b

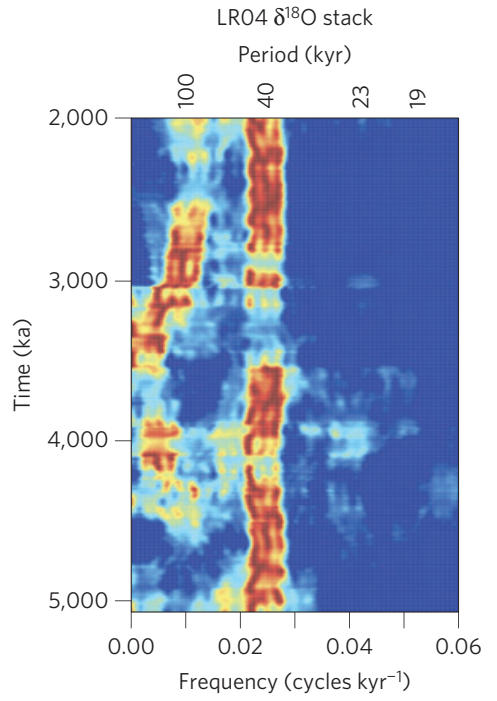

c

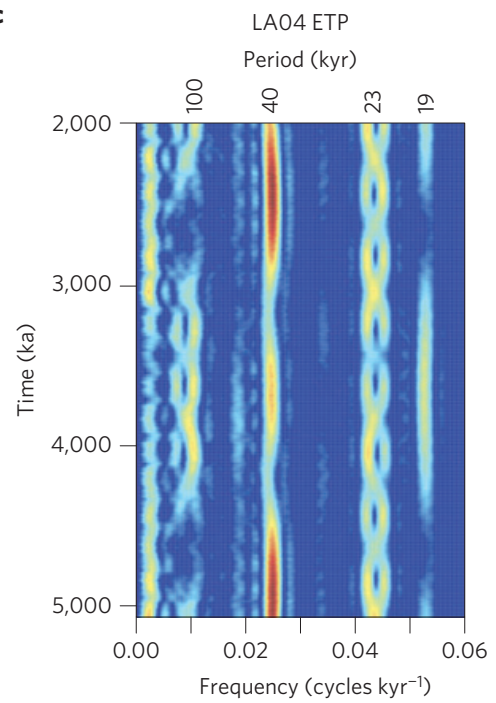

d

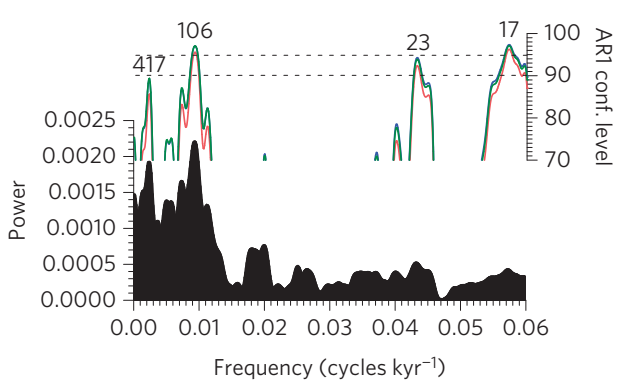

e

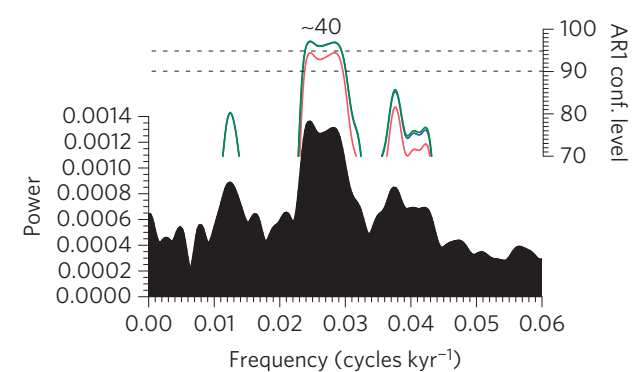

f

LR04:2,500-3,500 ka

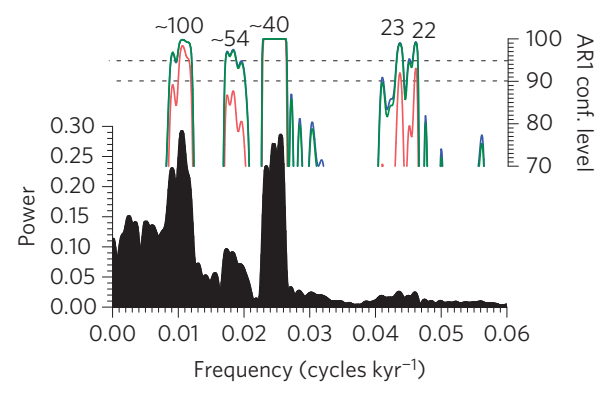

g

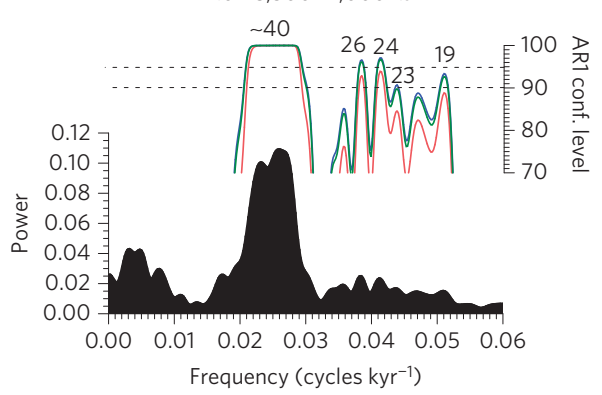

— ML96AR1

Figure 3 | $2 \pi$ MTM time-frequency analysis (500-kyr window) results. a, Normalized power for the untuned U1361 IBRD-MAR data ${ }^{12}$. b, Normalized power for the LRO4 $\delta^{18} \mathrm{O}$ stack$^{1}$. c. Amplitude for the eccentricity-tilt-precession (ETP) solution ${ }^{39}$. Power has been normalized such that the maximum power in each 500-kyr window is unity. $\mathbf{d}-\mathbf{g}, 2 \pi$ MTM power spectral estimates for the U1361 IBRD-MAR data using the untuned age model ${ }^{12}$ (d,e) and for the $\delta^{18} \mathrm{O} \operatorname{stack}^{1}(\mathbf{f}, \mathbf{g})$, with red noise confidence levels using three different approaches (Supplementary Information). In a-c, red indicates large values and blue indicates low values.

obliquity to precession dominance in the IBRD-MAR time series from U1361 (Figs 2 and 3a).

The observed $\sim 20$-kyr-duration IBRD cycles correlate with summer insolation calculated for $65^{\circ} \mathrm{S}$ for the interval of the core between 3.3 and 2.2 Ma (Figs 2 and 3a) and are embedded within 100-kyr-duration IBRD cycles, with an additional spectral peak at $\sim 400$ kyr nearing the $90 \%$ confidence level (Fig. 3d). Broad peaks of IBRD maxima are associated with transitions between laminated mudstones to diatom-rich/bearing muds (Fig. 2). A pronounced decrease in the amplitude of $\sim 20$-kyr IBRD peaks, and a change to lithofacies associated with non-erosive low-energy bottom currents, is observed at the core site above $\sim 2.5 \mathrm{Ma}$, broadly coincident with southern high-latitude cooling ${ }^{9}$ and the onset of major Northern Hemisphere glaciations ${ }^{25}$. We attribute the progressive reduction in calving intensity to cooling and a relative stabilization of the EAIS ice margin (discussed below). Homogenization of the turbidite sediments during glacial maxima by enhanced bioturbation and bottom current activity is observed and probably reflects increased Antarctic sea ice and polynya-style mixing at this time producing oxygenated high-salinity shelf water ${ }^{9}$ that is transferred downslope over Site U1361 to form Antarctic Bottom Water $^{26}$ (Supplementary Information).

In summary, our correlations of IBRD variations with the benthic $\delta^{18} \mathrm{O}$ stack and orbital time series identify up to seventeen $\sim 40$-kyr-duration cycles (orange dashed lines in Fig. 2) within six major lithological cycles (cycles 13-18, Fig. 2) during the Early Pliocene (4.3-3.5 Ma). This is followed by forty $\sim 20$-kyrduration cycles (blue dashed lines in Fig. 2), modulated by 
a

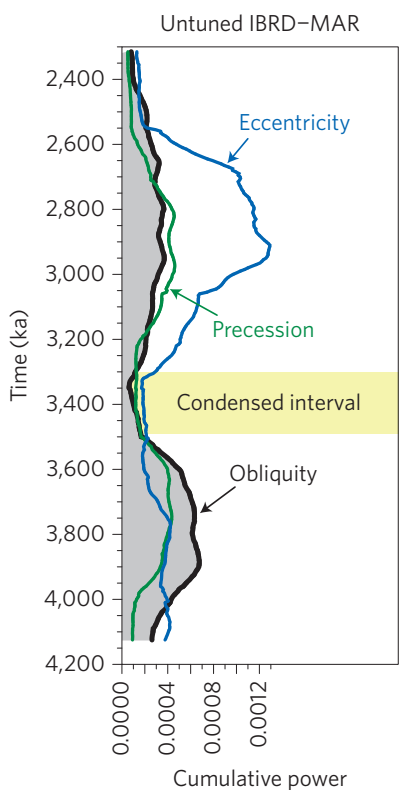

b

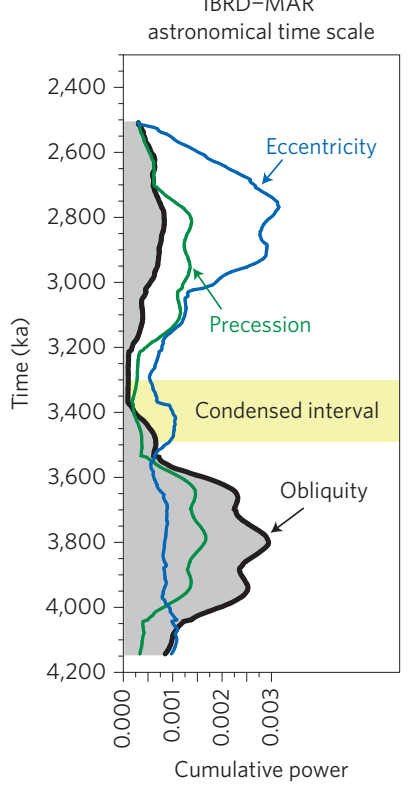

C

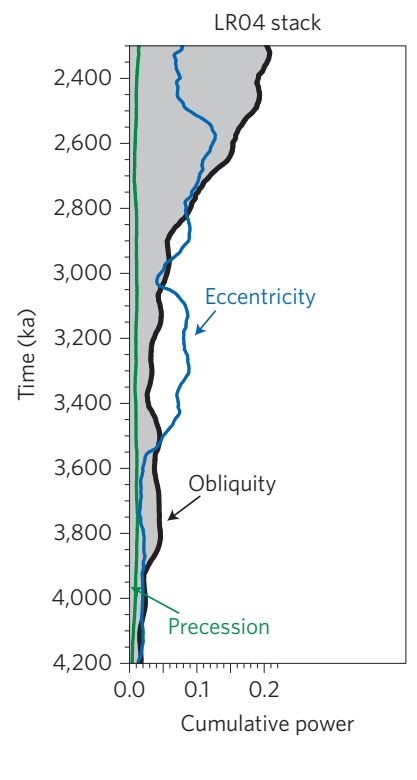

Figure 4 | Quantitative assessment of the evolution of power using the MTM time-frequency results. Cumulative power in the precession (0.04-0.06 cycles kyr ${ }^{-1}$ ), obliquity (0.02-0.035 cycles kyr ${ }^{-1}$ ), and eccentricity (0-0.015 cycles kyr ${ }^{-1}$ ) bands for untuned IBRD-MAR data (a), astronomically tuned IBRD-MAR data (using tie lines in Fig. 2) (b), and LRO4 $\delta^{18} \mathrm{O}$ stack $^{1}$ (c). These results indicate a generally dominant obliquity signal

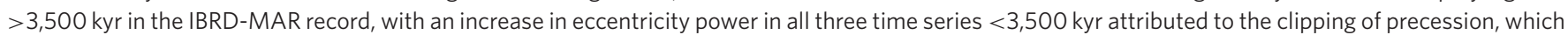
transfers precession power to its eccentricity modulator. Obliquity dominates again after $\sim 2.8$ Ma in the LRO4 $\delta^{18} \mathrm{O}$ stack, but not in the IBRD-MAR data.

eccentricity, that occur within twelve lithological cycles (cycles 1-12 Fig. 2).

Although the ANDRILL (AND-1B) marine sediment core from the Ross Sea region provided the first direct evidence that advance and retreat of the WAIS margin across the continental shelf was paced by obliquity during the Pliocene before $\sim 3 \mathrm{Ma}$ (ref. 7), subglacial erosion surfaces in the AND-1B core associated with ice advance have raised the possibility of missing cycles, particularly after 3.1 Ma-for example, the response of WAIS to orbital forcing is more ambiguous after this time. The U1361 and AND-1B records together confirm the dynamic response of both the WAIS and EAIS marine margins to obliquity forcing during the warm Pliocene before the onset of southern high-latitude cooling at 3.3 Ma (ref. 9).

Geologic records $\mathrm{s}^{7,9,17}$ and model simulations ${ }^{8}$ of past warm climates highlight the sensitivity of the marine-based portions of the Antarctic ice sheets to ocean warming. However, the mechanism by which the coastal ocean warms and destabilizes marine grounding lines, particularly in response to obliquity forcing, remains elusive. It has been proposed that changes in the intensity and meridional distribution of mean annual insolation controlled by obliquity may have a profound influence on the position and strength of the Southern Hemisphere zonal westerly winds, with implications for marine ice-sheet instability ${ }^{7}$. Indeed, an aerosolic dust record from the Southern Ocean is dominated by $\sim 40$-kyr cycles before $\sim 0.8 \mathrm{Ma}$ (ref. 27). Moreover, before $\sim 3.3 \mathrm{Ma}$ the southward expansion of the westerly wind field over the Antarctic circumpolar convergence zone under a reduced meridional temperature gradient has been associated with a reduced sea-ice field ${ }^{9}$. This may have caused the upwelling of warm, $\mathrm{CO}_{2}$-rich CDW onto the continental shelf, with consequences for the migration of marine grounding lines ${ }^{16,28,29}$.

The reduction in obliquity power revealed by our data after $\sim 3.5 \mathrm{Ma}$, and comparably stronger influence of precession and eccentricity (Figs $3 \mathrm{a}$ and 4 ), is interpreted to reflect a declining sensitivity of the EAIS to oceanic forcing as the southern high latitudes cooled. Both model and geologic reconstructions imply that past Antarctic ice-sheet expansion is closely linked with development of the sea-ice field ${ }^{30}$ potentially resulting in northward migration of westerly winds and Southern Ocean fronts ${ }^{9}$. Furthermore, sea-ice expansion after $3.5 \mathrm{Ma}$ (ref. 9) potentially restricted upwelling and ventilation of warm $\mathrm{CO}_{2}$-rich CDW at the Antarctic margin, acting to further enhance climate cooling. Under such a scenario, during the warmer climate state of the Early to mid-Pliocene with higher atmospheric $\mathrm{CO}_{2}$ concentration ${ }^{31,32}$, the increased duration and intensity of austral summer surface warming produced a pattern approaching mean annual insolation regulated by obliquity (Fig. 2d), rather than precession that cancels out over the course of a seasonal cycle ${ }^{5}$. Late Pliocene cooling raised the melt threshold such that the duration of the melt season was restricted to times of austral summer insolation maxima controlled by precession (Fig. 2c), and extending the winter sea-ice growth season ${ }^{33}$. We propose this decrease in $\mathrm{CO}_{2}$ radiative forcing resulted in extensive sea-ice cover extending into much of the summer season, limiting the influence of upwelling CDW on marine grounding line stability.

The significant variance at $\sim 20$-kyr precession and coincident increase in the $\sim 100$-kyr eccentricity frequency bands between 3.5 and $2.5 \mathrm{Ma}$ is intriguing (Figs 3a,d and 4), and is similar to the pattern of orbital response expressed in $\sim 100$-kyr-duration glacialinterglacial cycles in the benthic $\delta^{18} \mathrm{O}$ and greenhouse gas ice core records of the past $600 \mathrm{kyrs}$ (refs 34,35). Thus the relative dominance of eccentricity in EAIS variability at the Wilkes Land marine margin after 3.5 Ma may reflect a threshold response of the ice sheet to orbital forcing under a colder climate regime, as has been proposed to explain the relative dominance of $\sim 100$-kyr cycles in global Late Pleistocene ice volume, albeit with different mass balance forcings $s^{33,36,37}$. Here we propose that the precession response of perennial sea ice after 3.3 Ma was modulated by eccentricity (Fig. 4), such that the areal extent of sea ice was significantly reduced every $\sim 100 \mathrm{kyr}$, enhancing the influence of oceanic warming at those times. The observation of strong $\sim 100$-kyr and 400-kyr power is consistent with a nonlinear clipped climate response ${ }^{34}$, whereby precession power is transferred to its eccentricity modulator (Fig. 3d).

Our data are also consistent with a reduction of obliquity variance in the benthic $\delta^{18} \mathrm{O}$ (refs 1,38 ) at $\sim 3.5 \mathrm{Ma}$ (Fig. 3b), coincident with 
an obliquity node in the astronomical solution ${ }^{39}$. The gradual reemergence of a 40 -kyr signal at $\sim 3 \mathrm{Ma}$ in benthic $\delta^{18} \mathrm{O} \operatorname{record}^{38}$ (Figs $3 \mathrm{~b}$ and $4 \mathrm{c}$ ) most probably reflects a similar re-emergence of strong obliquity forcing in the orbital records and possibly also a direct response of the developing Northern Hemisphere continental ice sheets to obliquity forcing. However, it remains possible that precession-driven, anti-phase oscillations in both hemispheric icevolume histories may have cancelled out in globally integrated proxy records after 3-2.8 $\mathrm{Ma}$ (for example, ref. 4).

The strong obliquity signal seen in our IBRD record also suggests that the intensity of summer insolation was a not a direct control on the mass balance of the EAIS before $3.5 \mathrm{Ma}$. The geometry of strata on the Wilkes Land continental shelf indicate that the EAIS expanded towards the continental shelf edge during glacial maxima in the Pliocene ${ }^{12}$, indicating most Antarctic ice-volume variance at this time was growth and retreat of the marine-based ice sheets (Supplementary Fig. 1). During the Early Pliocene, when the sea-ice field was reduced and the Wilkes Land margin of the EAIS was in more direct contact with oceanic influences, iceberg calving occurred more regularly within both facies. Based on the significant decrease in IBRD after $2.5 \mathrm{Ma}$ (Fig. 2) and Southern Ocean records inferring decreased SSTs (refs 9,40), we also infer the marine margins of the EAIS became less sensitive to ocean-induced melting compared to the WAIS (ref. 29). After this time, East Antarctic ice volume probably fluctuated with a magnitude similar to that of Late Pleistocene cycles, with a minimal contribution to the $\delta^{18} \mathrm{O}$ signal ${ }^{8,21}$

Notwithstanding this relative stability of the marine-based sectors of the EAIS, model results suggest that $\sim 20$-kyr-duration fluctuations in the total Antarctic ice volume (that is, including the WAIS) may have contributed up to $15 \mathrm{~m}$ of the total amplitude during Late Pleistocene glacial-interglacial cycles ${ }^{8}$. Given the $\delta^{18} \mathrm{O}$ composition of Antarctic ice, this magnitude of variability could have offset a larger out-of-phase precessional change in Northern Hemisphere ice volume (for example, 20-40 m), resulting in an enhanced obliquity signal in globally integrated sea-level and ice-volume proxy records after 3.0-2.8 Ma (for example, ref. 4 , Figs $3 \mathrm{~b}$ and 4). Alternatively, direct obliquity forcing of the Northern Hemisphere ice sheet is supported by proxy evidence including ice-rafted debris records ${ }^{25}$ and a recent dust flux record ${ }^{41}$, suggesting that Northern Hemisphere ice-sheet variability (marinebased margins) and climate primarily responded to obliquity under a relatively warm Northern Hemisphere climate state. Northern Hemisphere cooling and ice-sheet growth across the midPleistocene transition $\sim 0.8 \mathrm{Ma}$ has been implicated in a similar switch to precession- and eccentricity-paced glaciations, albeit by different mass balance forcing mechanisms ${ }^{42}$. In contrast, however, our results imply that Southern Ocean sea-ice feedbacks caused a fundamentally different response of the marine-based sectors of the EAIS under a cooler Late Pliocene/Early Pleistocene climate state, characterized by a dominance of precession-paced variability.

We conclude that, before $3.5 \mathrm{Ma}$, under a warm climate state, EAIS demonstrates high sensitivity on orbital timescales to a relatively small increase in atmospheric $\mathrm{CO}_{2}$ concentration and mean global surface temperature. With atmospheric $\mathrm{CO}_{2}$ concentrations and global surface temperatures projected to remain above $400 \mathrm{ppm}$ and $>+2{ }^{\circ} \mathrm{C}$ beyond $2100^{43}$, our results have implications for the equilibrium response of the Antarctic ice sheets, and suggest that the marine margins of the EAIS, as well as the marine-based WAIS, may become increasingly susceptible to ocean warming, with the potential for widespread mass loss raising sea level by metres over the coming centuries to millennia.

\section{Methods}

20- $\mathrm{cm}^{3}$ samples were treated with $\mathrm{H}_{2} \mathrm{O}_{2}$ to remove organic material and $2 \mathrm{M} \mathrm{NaOH}$ to remove biogenic opal for grain size analysis. The MAR of the coarse-sand fraction was then estimated using the following equation:

\section{$\mathrm{IBRD} \mathrm{MAR}=\mathrm{CS} \% * \mathrm{DBD} * \mathrm{LSR}$}

where IBRD MAR is the mass accumulation rate $\left(\mathrm{g} \mathrm{cm}^{-2} \mathrm{kyr}^{-1}\right), \mathrm{CS} \%$ is the terrigenous coarse-sand weight per cent, DBD is the dry-bulk density of the nearest value $\left(\mathrm{g} \mathrm{cm}^{-3}\right)$ and LSR is the interval average linear sedimentation rate $\left(\mathrm{cm} \mathrm{kyr}^{-1}\right)$. Visual examination of every individual sample for authigenic minerals and volcanic glass was conducted-and these were absent, indicating that the IBRD volume per cent was directly equivalent to the terrigenous CS\% (ref. 44).

Following application of the biostratigraphic/magnetostratigraphic age model $^{12}$ and the astrochronologic age model derived in this study, we performed time series analysis using 'Astrochron: An R package for Astrochronology ${ }^{45}$. Before analysis, all data series were conservatively resampled on a 5-kyr grid using piecewise linear interpolation (the median sampling intervals for the IBRD-MAR data and benthic $\delta^{18} \mathrm{O}$ stack are $3 \mathrm{kyr}$ and $5 \mathrm{kyr}$, respectively). All spectral analyses used the multitaper method (MTM; ref. 46), with three $2 \pi$ prolate tapers. Time-frequency MTM was employed with a 500-kyr window (5-kyr step); each window was linearly detrended before analysis.

\section{Received 24 June 2014; accepted 16 September 2014;} published online 26 October 2014

\section{References}

1. Lisiecki, L. E. \& Raymo, M. E. A Plio-Pleistocene stack of 57 globally distributed benthic $\delta^{18} \mathrm{O}$ records. Paleoceanography 20, PA1003 (2005).

2. Miller, K. G. et al. High tide of the warm Pliocene: Implications of global sea level for Antarctic deglaciation. Geology 40, 407-410 (2012).

3. Hays, J. D., Imbrie, J. \& Shackleton, N. J. Variations in the Earth's Orbit: Pacemaker of the Ice Age. Science 194, 1121-1132 (1976).

4. Raymo, M. E., Lisiecki, L. E. \& Nisancioglu, K. H. Plio-Pleistocene ice volume Antarctic climate, and the global $\delta^{18} \mathrm{O}$ record. Science 28, $492-495$ (2006)

5. Huybers, P. \& Tziperman, E. Integrated summer insolation forcing and 40,000-year glacial cycles: The perspective from an ice-sheet/energy-balance model. Paleoceanography 23, PA1208 (2008)

6. Raymo, M. E. \& Huybers, P. Unlocking the mysteries of the ice ages. Nature 451, 284-285 (2008).

7. Naish, T. et al. Obliquity-paced Pliocene West Antarctic ice sheet oscillations. Nature 458, 322-328 (2009).

8. Pollard, D. \& DeConto, R. Modeling West Antarctic ice sheet growth and collapse through the past five million years. Nature 458, 329-332 (2009).

9. McKay, R. et al. Antarctic and Southern Ocean influences on late Pliocene global cooling. Proc. Natl Acad. Sci. USA 109, 6423-6428 (2012).

10. Fretwell, P. et al. Bedmap2: Improved ice bed, surface and thickness datasets for Antarctica. Cryosphere 7, 375-393 (2013)

11. Lucchi, R. G. et al. Mid-late Pleistocene glacimarine sedimentary processes of a high-latitude, deep-sea sediment drift (Antarctic Peninsula Pacific margin). Mar. Geol. 189, 343-370 (2002).

12. Tauxe, L. et al. Chronostratigraphic framework for the IODP Expedition 318 cores from the Wilkes Land margin: Constraints for paleoceanographic reconstruction. Paleoceanography 27, PA2214 (2012).

13. Eittreim, S. L., Cooper, A. K. \& Wannesson, J. Seismic stratigraphic evidence of ice-sheet advances on the Wilkes Land margin of Antarctica. Sedim. Geol. 96, 131-156 (1995).

14. Escutia, C. et al. Cenozoic ice sheet history from east Antarctic Wilkes Land continental margin sediments. Glob. Planet. Change 45, 51-81 (2005).

15. Anderson, R. F. et al. Wind-driven upwelling in the Southern Ocean and the deglacial rise in atmospheric $\mathrm{CO}_{2}$. Science 323, 1443-1448 (2009).

16. Toggweiler, J. R., Russell, J. L. \& Carson, S. R. Midlatitude westerlies, atmospheric $\mathrm{CO}_{2}$, and climate change during the ice ages. Paleoceanography 21, PA2005 (2006)

17. Cook, C. P. et al. Dynamic behaviour of the East Antarctic ice sheet during the Pliocene warmth. Nature Geosci. 6, 765-769 (2013).

18. Depoorter, M. A. et al. Calving fluxes and basal melt rates of Antarctic ice shelves. Nature 502, 82-92 (2013).

19. Joughin, I., Alley, R. B. \& Holland, D. M. Ice-sheet response to oceanic forcing Science 338, 1172-1176 (2012)

20. Barrett, P. J. Resolving views on Antarctic Neogene glacial history-the Sirius debate. Earth Environ. Sci. Trans. R. Soc. Edinburgh 104, 31-53 (2013).

21. Mackintosh, A. et al. Retreat of the East Antarctic ice sheet during the last glacial termination. Nature Geosci. 4, 195-202 (2011).

22. Weber, M. E. et al. Millennial-scale variability in Antarctic ice-sheet discharge during the last deglaciation. Nature 510, 134-138 (2014).

23. Zachos, J. et al. Climate response to orbital forcing across the Oligocene-Miocene boundary. Science 292, 274-276 (2001). 
24. Pälike, H. et al. The heartbeat of the Oligocene climate system. Science 314, 1894-1898 (2006).

25. Kleiven, H. F., Jansen, E., Fronval, T. \& Smith, T. M. Intensification of Northern Hemisphere glaciations in the circum Atlantic region (3.5-2.4 Ma)-ice-rafted detritus evidence. Palaeogeogr. Palaeoclimatol. Palaeoecol. 184, 213-223 (2002).

26. Williams, G. D., Bindoff, N. L., Marsland, S. J. \& Rintoul, S. R. Formation and export of dense shelf water from the Adélie depression, East Antarctica. J. Geophys. Res. 113, C04039 (2008).

27. Martínez-Garcia, A. et al. Southern Ocean dust-climate coupling over the past four million years. Nature 476, 312-315 (2011).

28. Martinson, D. G., Stammerjohn, S. E., Iannuzzi, R. A., Smith, R. C. \& Vernet, M. Western Antarctic Peninsula physical oceanography and spatio-temporal variability. Deep-Sea Res. II 55, 1964-1987 (2008).

29. Pritchard, H. D. et al. Antarctic ice-sheet loss driven by basal melting of ice shelves. Nature 484, 502-505 (2012).

30. DeConto, R., Pollard, D. \& Harwood, D. Sea ice feedback and Cenozoic evolution of Antarctic climate and ice sheets. Paleoceanography 22, PA3214 (2007).

31. Pagani, M., Liu, Z., LaRiviere, J. \& Ravelo, A. C. High Earth-system climate sensitivity determined from Pliocene carbon dioxide concentrations. Nature Geosci. 3, 27-30 (2010).

32. Seki, O. et al. Alkenone and boron-based Pliocene $\mathrm{pCO}_{2}$ records. Earth Planet. Sci. Lett. 292, 201-211 (2010).

33. Huybers, P. \& Denton, G. Antarctic temperature at orbital timescales controlled by local summer duration. Nature Geosci. 1, 787-792 (2008).

34. Imbrie, J. et al. On the structure and origin of major glaciation cycles 2 . The 100,000-year cycle. Paleoceanography 8, 699-735 (1993).

35. Jouzel, J. et al. Orbital and millennial Antarctic climate variability over the past 800,000 years. Science 317, 793-796 (2007).

36. Raymo, M. E., Oppo, D. W. \& Curry, W. The Mid-Pleistocene climate transition: A deep sea carbon isotopic perspective. Paleoceanography 12, 546-559 (1997).

37. Raymo, M. E. The timing of major climate terminations. Paleoceanography 12, 577-585 (1997).

38. Meyers, S. R. \& Hinnov, L. A. Northern Hemisphere glaciation and the evolution of Plio-Pleistocene climate noise. Paleoceanography 25, PA3207 (2010).

39. Laskar, J. et al. A long-term numerical solution for the insolation quantities of the Earth. Astron. Astrophys. 428, 261-285 (2004).

40. Escutia, C. et al. Circum-Antarctic warming events between 4 and $3.5 \mathrm{Ma}$ recorded in marine sediments from the Prydz Bay (ODP Leg 188) and the
Antarctic Peninsula (ODP Leg 178) margins. Glob. Planet. Change 69, 170-184 (2009).

41. Naafs, B. D. A. et al. Strengthening of North American dust sources during the late Pliocene (2.7 Ma). Earth Planet. Sci. Lett. 317, 8-19 (2012).

42. Huybers, P. Early Pleistocene glacial cycles and the integrated summer insolation forcing. Science 313, 508-511 (2006).

43. IPCC Climate Change 2013: The Physical Science Basis (Cambridge Univ. Press, 2013).

44. Krissek, L. A. in Proc. ODP, Sci. Results vol 145 (eds Rea, D. K., Basov, I. A., Scholl, D. W. \& Allan, J. F.) 179-194 (Ocean Drilling Program, 1995).

45. Meyers, S. R. Astrochron: An R Package for Astrochronology (R Foundation for Statistical Computing, 2014); http://cran.r-project.org/package=astrochron

46. Thomson, D. J. Spectrum estimation and harmonic analysis. Proc. IEEE 70, 1055-1096 (1982).

\section{Acknowledgements}

This research used samples and data provided by the Integrated Ocean Drilling Program (IODP). The IODP is sponsored by the US National Science Foundation (NSF) and participating countries under the management of Joint Oceanographic Institutions. Financial support for this study was provided to T.N. and R.M. from the Royal Society of New Zealand Marsden Fund Contract VUW0903, and Rutherford Discovery Fellowship (RDF-13-VUW-003) to R.M. Additional support was provided by the Ministry of Science and Innovation (Grant CTM-2011-24079) to C.E. and by MEXT to F.J.J-E., and by the US NSF (Grant OCE-1003603) to S.R.M. and US NSF (Grant OCE-1202632) to M.E.R.

\section{Author contributions}

M.O.P., R.M. and T.N. designed the study, conducted sedimentological and time series analyses and wrote the paper. S.R.M. carried out time-frequency analysis and interpretations. C.E. and H.B. led IODP Expedition 318 and provide seismic reflection data interpretation. F.J.J-E. and C.E. analysed XRF geochemical data. L.T. led development of the age model. M.E.R. contributed to writing the manuscript. All authors contributed to the interpretations.

\section{Additional information}

Supplementary information is available in the online version of the paper. Reprints and permissions information is available online at www.nature.com/reprints. Correspondence and requests for materials should be addressed to R.M.

\section{Competing financial interests}

The authors declare no competing financial interests.

\begin{abstract}
A. Klaus ${ }^{8}$, A. Fehr ${ }^{9}$, J. A. P. Bendle ${ }^{10}$, P. K. Bijl11 , S. M. Bohaty ${ }^{12}$, S. A. Carr ${ }^{13}$, R. B. Dunbar ${ }^{14}$, J. A. Flores ${ }^{15}$, J. J. Gonzalez ${ }^{16}$, T. G. Hayden ${ }^{17}$, M. Iwai ${ }^{18}$, K. Katsuki ${ }^{19}$, G. S. Kong ${ }^{20}$, M. Nakai ${ }^{21}$, M. P. Olney ${ }^{22}$, S. Passchier ${ }^{23}$, S. F. Pekar ${ }^{24}$, J. Pross ${ }^{25}$, C. R. Riesselman ${ }^{26}$, U. Röh ${ }^{27}$, T. Sakai ${ }^{28}$, P. K. Shrivastava ${ }^{29}$, C. E. Stickley ${ }^{30}$, S. Sugasaki ${ }^{31,32}$, S. Tuo ${ }^{33}$, T. van de Flierdt ${ }^{34}$, K. Welsh ${ }^{35}$, T. Williams ${ }^{36}$ and M. Yamane ${ }^{3}$
\end{abstract}

${ }^{8}$ United States Implementing Organization, Integrated Ocean Drilling Program, Texas A\&M University, 1000 Discovery Drive, College Station, Texas 77845, USA, ${ }^{9}$ Institute for Applied Geophysics and Geothermal Energy, RWTH Aachen University, Mathieustrasse 6, D-52074 Aachen, Germany,

${ }^{10}$ Geography, Earth and Environmental Sciences, University of Birmingham, Edgbaston, B15 2TT, UK, 11 Marine Palynology and Paleoceanography, Laboratory of Palaeobotany and Palynology, Department of Earth Sciences, Faculty of Geosciences, Utrecht University, Budapestlaan 4, 3584 CD, Utrecht, The Netherlands, ${ }^{12}$ Ocean and Earth Science, National Oceanography Centre Southampton, University of Southampton, European Way, SO14 3ZH, Southampton, UK, ${ }^{13}$ Department of Civil \& Environmental Engineering, Colorado School of Mines, 1500 Illinois Street, Golden, Colorado 80401, USA, ${ }^{14}$ Department of Environmental Earth System Science, Stanford University, 325 Braun Hall, Building 320, Stanford, California 94305-2115, USA, ${ }^{15}$ Department of Geology, Universidad de Salamanca, 37008 Salamanca, Spain, ${ }^{16}$ Instituto Andaluz de Ciencias de la Tierra, CSIC-UGR, 18100 Armilla, Spain, ${ }^{17}$ Department of Geology, Western Michigan University, 1187 Rood Hall, 1903 West Michigan Avenue, Kalamazoo, Michigan 49008, USA, ${ }^{18}$ Department of Natural Science, Kochi University, 2-5-1 Akebono-cho, Kochi 780-8520, Japan, ${ }^{19}$ Geological Research Division, Korea Institute of Geoscience and Mineral Resources, 30 Gajeong-dong, Yuseong-gu, Daejeon 305-350, Republic of Korea, ${ }^{20}$ Petroleum and Marine Research Division, Korea Institute of Geoscience and Mineral Resources, 30 Gajeong-dong, Yuseong-gu, Daejeon 305-350, Republic of Korea, ${ }^{21}$ Education Department, Daito Bunka University, 1-9-1 Takashima-daira, Itabashi-ku, Tokyo 175-8571, Japan, 22Department of Geology, University of South Florida, Tampa, 4202 East Fowler Avenue, SCA 528, Tampa, Florida 33620, USA, ${ }^{23}$ Earth and Environmental Studies, Montclair State University, 252 Mallory Hall, 1 Normal Avenue, Montclair, New Jersey 07043, USA, ${ }^{24}$ School of Earth and Environmental Sciences, Queens College, 65-30 Kissena Boulevard, Flushing, New York 11367, USA, ${ }^{25}$ Paleoenvironmental Dynamics Group, Institute of Earth Sciences, University of Heidelberg, Im Neuenheimer Feld 234, 69120 Heidelberg, Germany, ${ }^{26}$ Departments of Geology and Marine Science, University of Otago, PO Box 56, Dunedin 9054, New Zealand, ${ }^{27}$ MARUM-Center for Marine Environmental Sciences, University of Bremen, Leobener Straße, 28359 Bremen, Germany, ${ }^{28}$ Department of Geology, Utsunomiya University, 350 Mine-Machi, Utsunomiya 321-8505, Japan, ${ }^{29}$ Antarctica Division, Geological Survey of India, NH5P, NIT, Faridabad 121001, Haryana, India, ${ }^{30}$ Evolution Applied Limited, 50 Mitchell Way, Upper Rissington, Cheltenham, Gloucestershire, GL7 3SF, UK, ${ }^{31}$ Scripps Institution of Oceanography, University of California, San Diego, La Jolla, California 92093-0220, USA, 32 Department of Earth and Planetary Sciences, University of Tokyo, 7-3-1 Hongo, Bunkyo-ku, Tokyo 113-0033, Japan, ${ }^{33}$ State Key Laboratory of Marine Geology, Tongji University, 1239 Siping Road, Shanghai 200092, China, ${ }^{34}$ Department of Earth Science and Engineering, Imperial College London, South Kensington Campus, Prince Consort Road, London SW7 2AZ, UK, 35 School of Earth Sciences, University of Queensland, St Lucia, Brisbane, Queensland 4072, Australia, ${ }^{36}$ Lamont-Doherty Earth Observatory of Columbia University, 61 Route 9 W, Palisades, New York 10964, USA. 